\title{
Nearshore exposure to Deepwater Horizon oil
}

\author{
Shahrokh Rouhani ${ }^{1, *}$, Mary C. Baker ${ }^{2}$, Marla Steinhoff ${ }^{2}$, Mengni Zhang ${ }^{1}$, \\ Jacob Oehrig ${ }^{1}$, Ian J. Zelo ${ }^{2}$, Stephen D. Emsbo-Mattingly ${ }^{3}$, Zachary Nixon ${ }^{4}$, \\ Jonathan M. Willis ${ }^{5}$, Mark W. Hester ${ }^{5}$ \\ ${ }^{1}$ NewFields Companies LLC, 1349 W. Peachtree Street, Suite 2000, Atlanta, GA 30309, USA \\ ${ }^{2}$ National Oceanic and Atmospheric Administration, Assessment and Restoration Division, 7600 Sand Point Way NE, Seattle, \\ WA 98115, USA \\ ${ }^{3}$ NewFields Companies LLC, 300 Ledgewood Place, Suite 305, Rockland, MA 02370, USA \\ ${ }^{4}$ Research Planning Inc., 1121 Park St., Columbia, SC 29201, USA \\ ${ }^{5}$ Institute for Coastal and Water Research, Department of Biology, University of Louisiana at Lafayette, Lafayette, LA 70504, USA
}

\begin{abstract}
The Deepwater Horizon (DWH) oil spill affected more than $2000 \mathrm{~km}$ of shoreline. DWH oil entered the nearshore environment, stranding on shorelines as tar balls and/or emulsified oil, or forming submerged oil mats and integrating into nearshore sediments. The available chemistry data showed submerged sediments, especially within the first $50 \mathrm{~m}$ from oiled shorelines, displayed patchy distributions of elevated polycyclic aromatic hydrocarbon (PAH) concentrations in excess of ambient concentrations, which were quantified based on forensic findings establishing their source as being from the Macondo oil. Consistent with observed shoreline oiling conditions, PAH concentrations in the soils of affected Louisiana coastal wetlands were orders of magnitude higher than ambient concentrations, especially in locations along the seaward edge of the marsh. Both total and petrogenic PAHs decreased with distance from the shore in both inland and offshore directions. Although PAHs exhibited evidence of weathering over time, in the most heavily oiled areas, they continued to exceed ambient concentrations by orders of magnitude through fall of 2013.
\end{abstract}

KEY WORDS: Deepwater Horizon oil spill · National resources damage assessment - NRDA · Salt marsh $\cdot$ Nearshore $\cdot$ Submerged oil $\cdot$ PAH $\cdot$ Louisiana

\section{INTRODUCTION}

On April 20 2010, an explosion aboard the Deepwater Horizon (DWH), a mobile, offshore Macondo prospect (Mississippi Canyon 252 or MC252) oil drilling rig in the northern Gulf of Mexico (GOM), caused the largest and most prolonged offshore oil spill in United States history. Response activities included application of large quantities of dispersants both at the wellhead and to offshore waters. As the oil traveled upward from the wellhead through the $1.5 \mathrm{~km}$ water column, it formed expansive surface oil slicks. Some of this oil was transported to nearshore communities by wind, currents, and water turbulence. Satellite imagery and other remote-sensing in-

${ }^{*}$ Corresponding author: srouhani@newfields.com

${ }^{\S}$ Advance View was available online October 23, 2016 formation demonstrated that the floating oil entered nearshore and estuarine areas of the northern Gulf of Mexico beginning in May 2010. Boufadel et al. (2014) estimated that 10000 to 30000 tons out of more than 440000 tons of oil mass released reached the shoreline of GOM, affecting more than $2000 \mathrm{~km}$ of beach and marsh shorelines, of which more than $700 \mathrm{~km}$ were moderately to heavily oiled (Nixon et al. 2016).

DWH oil in the nearshore environment consisted of 4 distinct components: (1) floating oil slicks, sheens, and emulsions; (2) stranded oil in the form of tar balls and/or emulsified oil, which reached the land via tidal fluctuations, wind, and storm events; (3) submerged oil, which either sank when encountering suspended sediment in surface water or was trans-

(C) The authors 2017. Open Access under Creative Commons by Attribution Licence. Use, distribution and reproduction are unrestricted. Authors and original publication must be credited.

Publisher: Inter-Research · www.int-res.com 


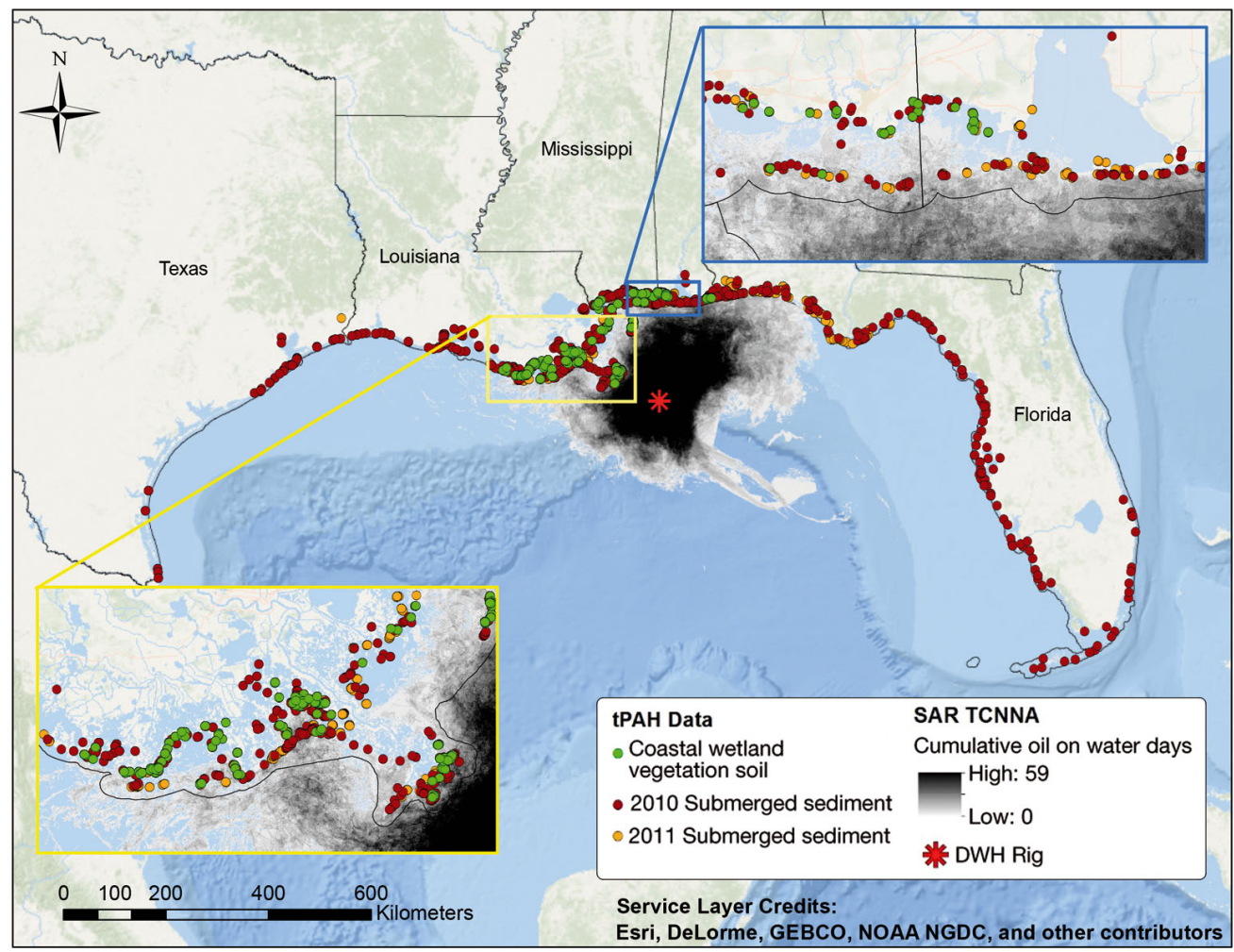

Fig. 1. Spatial distribution of oil on water and the nearshore chemistry data records in the Gulf of Mexico following the Deepwater Horizon (DWH) oil spill. Total polycyclic aromatic hydrocarbon (tPAH) data include coastal wetland vegetation soil samples (sampled from 2010 to 2013) and nearshore submerged sediment samples (sampled in 2010 and 2011). Daily extents of oil on water were delineated using SAR (synthetic aperture radar) images processed using the texture-classifying neural network algorithm (TCNNA)

ported via hydrodynamic wave action as it encountered surf resulting in flocculants, submerged oil mats (SOMs), and occasionally buoyant layers that appeared to be emulsified/oxidized oil and detritus (I. Zelo pers. comm.); and (4) dissolved oil present in nearshore water (Driskell \& Payne 2015). The 4 components interact with each other. For example, stranded oil on shorelines can be re-mobilized to become submerged oil. The interactions among these components determined the fate of DWH oil within the nearshore environment.

The purposes of this study were: (1) to evaluate the spatial and temporal characteristics of nearshore submerged DWH oil; (2) to summarize the available polycyclic aromatic hydrocarbon (PAH) concentration data collected within coastal wetland environments in the northern $\mathrm{GOM}_{\text {; }}$ and (3) to compare DWH oil exposures in various nearshore environment components and develop a conceptual model of nearshore exposure to DWH oil. Consistent with approaches used in past oil spills, PAH concentrations were used in order to indicate oil exposure and presence, determine the extent, magnitude and source of contamination, and evaluate the recovery of exposed resources over time (O'Clair et al. 1996, Readman et al. 1996, Short et al. 1996, Carls et al. 2001, Brandt et al. 2002, Wang \& Christensen 2006).

\section{MATERIALS AND METHODS}

In order to quantitatively evaluate the exposure of the nearshore environment to DWH oil, more than 30000 oil, soil, sediment, and tissue samples were collected. The present study focuses on US coastal wetland vegetation (CWV) soil data (1894 samples), which were collected between 2010 and 2013, and nearshore submerged sediment data (1731 samples), which were collected in 2010 and 2011, as depicted in Fig. 1.

\section{CWV soil sampling design}

As part of the natural resources damage assessment (NRDA), shoreline and plant oiling were recorded between May and September 2010 at 2779 
locations along the coastline of the northern GOM from White Lake in western Louisiana through Saint Marks in Florida (NOAA 2010), referred to as preassessment (PA) surveys. These surveys were intended to provide a global assessment of vegetation oiling conditions along the shoreline, although some locations experienced oiling after surveys were completed. The compiled information included observations of plant species, height of dominant vegetation, sediment oiling, and maximum length of oiled portions of plant stems. Plant stem oiling was computed as the ratio of oiled portion of plant stems to dominant vegetation mean height, and was used in the development of the subsequent CWV sampling plan (NOAA 2011a). The CWV sites in Louisiana were selected from PA sites using a stratified random sampling plan. Specifically, the PA sites along Louisiana vegetated shorelines were divided into 20 strata according to 5 classes of plant stem oiling and 4 habitat types. Plant stem oiling classes observed during PA surveys (hereafter 'PA plant oiling classes') were: (1) $0 \%$, which served as the reference condition; (2) $0-10 \%$ (or trace to $10 \%$ ); (3) $>10$ to $50 \%$; (4) $>50$ to
$90 \%$; and (5) >90 to $100 \%$. The 4 Louisiana habitat types were: (1) mainland herbaceous salt marsh; (2) back barrier herbaceous salt marsh; (3) coastal mangrove marsh; and (4) delta Phragmites marsh. Within each stratum, a given number of PA sites were randomly selected for CWV surveys to attain at least $95 \%$ confidence $(\alpha=5 \%)$ and $80 \%$ power $(\beta=20 \%)$. Each Louisiana mainland herbaceous salt marsh stratum contained the same number of selected sites. Such a balanced plan could not be achieved in other Louisiana habitats due to limited numbers of PA sites in various oiling classes. In Mississippi and Alabama, all the oiled PA sites were selected, with an equal number of reference sites included for CWV surveys (Willis et al. 2016). In total, 188 CWV sites were selected and repeatedly surveyed across the GOM over multiple seasons. The areal extent is depicted in Fig. 2 and the dates of surveys are listed in Table 1.

A transect was established at each CWV site. The initial transect length for the oiled Louisiana herbaceous marsh sites (mainland and back barrier) was set as the maximum visually observed extent of oil penetration as determined by either the PA survey or
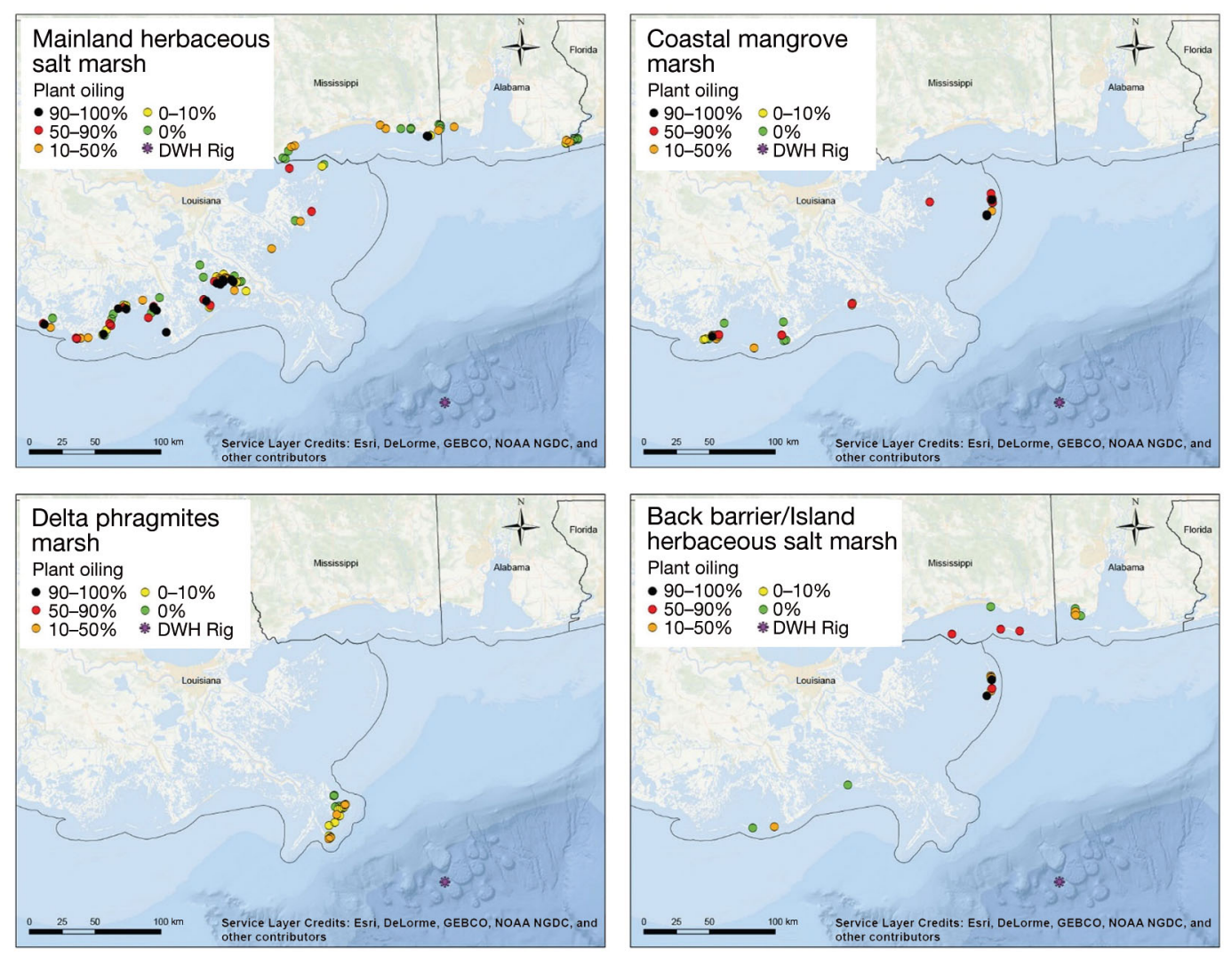

Fig. 2. Distribution of coastal USA wetland vegetation (CWV) sampling sites following the Deepwater Horizon (DWH) oil spill by habitat type and pre-assessment (PA) plant oiling class. Plant stem oiling was computed as the ratio of oiled portion of plant stems to dominant vegetation mean height 
Table 1. Details of coastal wetland vegetation surveys carried out following the Deepwater Horizon (DWH) oil spill in April 2010. Dates are shown as mm/dd/yyyy

\begin{tabular}{|c|c|c|c|c|}
\hline $\begin{array}{l}\text { Survey } \\
\text { season }\end{array}$ & Start & Finish & Extent of survey $\longrightarrow$ Inv & $\begin{array}{l}\text { nvestigated } \\
\text { sites }\end{array}$ \\
\hline Fall 2010 & $9 / 16 / 2010$ & $1 / 7 / 2011$ & All Louisiana sites & 150 \\
\hline Spring 2011 & $4 / 9 / 2011$ & $6 / 8 / 2011$ & All Louisiana, Mississippi and Alabama sites & 188 \\
\hline Fall 2011 & 9/17/2011 & $11 / 2 / 2011$ & All Louisiana, Mississippi and Alabama sites & 188 \\
\hline Fall 2012 & 9/10/2012 & $12 / 9 / 2012$ & All Louisiana, Mississippi and Alabama sites & 188 \\
\hline Fall 2013 & $9 / 23 / 2013$ & $12 / 13 / 2013$ & Louisiana (mainland + mangrove) sites, Mississippi and Alabama sites & 152 \\
\hline
\end{tabular}

CWV transect establishment team. The observed length of oil penetration into the vegetation varied from 2.9 to $30.0 \mathrm{~m}$. The results indicate higher mean penetration lengths along heavily oiled sites with 90 to $100 \%$ plant oiling. The transect lengths for other CWV sites were set at $20 \mathrm{~m}$ or the maximum feasible length. Each transect had 1 to 3 fixed locations (Zone 1, Zone 2, and Zone 3) representing edge and interior exposure zones, with a minimum of a $1 \mathrm{~m}$ buffer maintained between zones. The center of the edge (or Zone 1) was located approximately $1.5 \mathrm{~m}$ inland from the shoreline during the initial setup, the center of Zone 2 was located inland of the shoreline at $50 \%$ of the transect length, and the center of Zone 3 was located inland of the shoreline at $80 \%$ of the transect length (NOAA 2011a).

Each zone contained observation ('cover') and sampling ('productivity') plots. Surface soil-scoop samples were collected from the 4 corners of the $0.25 \mathrm{~m}^{2}$ portions of the productivity plots and placed in 4-ounce jars for PAH measurement. These samples were homogenized and composited at the laboratory prior to the PAH analysis. Grain size and total organic carbon (TOC) samples were measured by using two $7.2 \mathrm{~cm}$ outer-diameter core samples collected from each plot to a depth of $10 \mathrm{~cm}$. These samples were analyzed separately in the laboratory. The reported grain size and TOC values were the arithmetic averages of individual reported values per zone. All the soil samples were kept cold $\left(4^{\circ} \mathrm{C}\right.$ or on ice) during storage prior to analysis.

\section{Submerged sediment sampling design}

Submerged sediment data were collected in 2010 and 2011. The compiled 2010 submerged sediment samples were grouped as either pre- or post-spill, depending on their location and sampling date relative to the cumulative daily oil-on-water maps (Graettinger et al. 2015). Many of these samples were clustered around shorelines of concern and thus did not provide widespread spatial coverage. The 2011 submerged sediment data were collected as part of the NRDA's marsh edge sandy shore (MESSh) survey. Data were collected from 180 marsh-edge and 151 beach sites, which were selected based on a number of stratified random sampling plans across Louisiana, Mississippi, Alabama, and Florida (NOAA $2011 b, c)$. The marsh-edge sites were co-located with the CWV sites. The beach sites were primarily colocated with the 2010 summer PA sites and were stratified by state and shoreline oiling exposures. Between July and September 2011, 2 replicate transects, $100 \mathrm{~m}$ apart, were established at each site perpendicular to the shore on each side of the site center point. Transects were divided into 4 intervals extending to $0-10,10-20,20-50$, and $50-500 \mathrm{~m}$ from the shore. At each transect, $10 \mathrm{~cm}$ or $7.6 \mathrm{~cm}$ outer diameter cores were collected at random within each of the 4 intervals across 2 depth horizons $(0-2$ and 2-4 cm). An electronic number generator was used to ensure the random selection of sampling locations within the intervals. Prior to PAH analyses, all collected sediment samples were subjected to laboratory total petroleum hydrocarbons (TPH) screening for presence of oil-related compounds (NOAA 2011b). Samples indicating likely presence of oil, along with their nearby unoiled samples, were subjected to PAH analysis. A minimum of 2 samples per site were selected randomly and analyzed for PAHs from any site without an oiled sediment sample.

\section{Chemistry data}

The primary exposure data summarized in this work are total polycyclic aromatic hydrocarbon (tPAH) surrogate-corrected concentrations, calculated based on the summation of $50 \mathrm{PAH}$ analytes including parent PAHs and selected alkylated homologs listed in Forth et al. (2015). If the concentration of a given compound in a sample was not detected, it was treated as a 0 value in the summation. PAHs, in- 
cluding alkyl homologues, were analyzed in compliance with modified EPA method 8270D (EPA 2007), utilizing gas chromatography with low resolution mass spectrometry in the selected ion monitoring mode.

A quarter of the CWV soil samples and three-quarters of the nearshore submerged sediment samples evaluated in this work were also subjected to forensic analysis. Based on evaluation of dominant hydrocarbon types, quantitative comparison of diagnostic geochemical biomarker source ratios and spatial proximity to other indicators of DWH oil, the investigated samples were categorized into 5 match classification codes (Emsbo-Mattingly 2015a), i.e. A: consistent with fresh or weathered DWH oil; B: mostly consistent with fresh or weathered DWH oil; C: some weathered DWH oil may be present; D: indeterminate; or E: elevated presence of non-DWH oil. A description of the forensic analysis procedure is provided in the Supplement at www.int-res.com/ articles/suppl/m576p111_supp.pdf (see also Table S1 in the Supplement). Match code A and B (A/B) samples were further analyzed to quantify the depletion of DWH oil, which was computed as the percent change of the ratio of petrogenic PAHs to hopane in each sample relative to the ratio of the fresh DWH oil (Emsbo-Mattingly 2015a). All chemistry and forensic data were compiled in 2 web-based sources maintained by the National Oceanic and Atmospheric Administration (NOAA): Data Integration Visualization Exploration and Reporting (DIVER) (https:// dwhdiver.orr.noaa.gov/); and Environmental Response Management Application (ERMA®) (http:// response.restoration.noaa.gov/erma/).

\section{Statistical summarization of CWV soil chemistry data}

The tPAH CWV soil data were grouped by state/ region, habitat, season, PA plant oiling class, and zone. Mississippi and Alabama sites along the Mississippi Sound were treated as members of one state/ region group. Reported statistics of each group included sample size, mean, standard error, minimum, and maximum. In addition, when sample sizes exceeded 4, p-values corresponding to significances of 2-sample tests between tPAH concentrations at oiled groups and their corresponding reference values were calculated. For this purpose, parametric $t$ test and non-parametric Mann-Whitney $U$-tests were used concurrently. The computed $t$-test significances and standard errors were weighted and corrected for finite populations. A plant oiling group was considered as having significantly higher tPAH concentrations if its mean exceeded the corresponding reference value with a $p$-value $\leq 0.05$.

Additional summarizations were performed by considering shoreline oiling exposure categories as the domains of study (Cochran 1977). These oiling categories were established via repeated shoreline oiling observations made from May 5, 2010 to March 25, 2014 as part of the Shoreline Cleanup Assessment Technique (SCAT) and Shoreline Rapid Assessment (RA) surveys (Nixon et al. 2016). The SCAT teams systematically surveyed fixed, linear segments of shoreline post-spill to support decision-making for shoreline cleanup. RA surveys focused on linear along-shore zones across a subset of the potentially impacted CWV areas in Louisiana. Each shoreline segment was assigned to a specific oil exposure category based on the observed maximum precedent oiling conditions. Shoreline oiling exposure categories for vegetated shorelines consisted of (1) heavier persistent oiling (heavy or moderate oiling was observed repeatedly over a period of $12 \mathrm{wk}$ or longer); (2) heavier oiling (moderate or heavy oiling persisted for less than $12 \mathrm{wk}$ ); (3) lighter oiling (only trace to light oiling was observed); (4) no oil observed; and (5) not surveyed.

For the purposes of shoreline oiling summarizations and to avoid biases given the stratified random CWV sampling design from finite PA site populations, each tPAH measurement was assigned a sampling weight in accordance to its state/region, habitat, and plant oiling stratum. The sampling weight was calculated as the number of PA sites in a stratum divided by its corresponding number of CWV sites (Cochran 1977). All computations were performed using R package survey (R version 3.2.0) and verified by SPSS Complex Samples (IBM SPSS version 23).

\section{Statistical summarization of submerged sediment chemistry data}

The 2011 MESSh survey resulted in 5182 submerged sediment samples. Although screening determined 4326 of these samples as unoiled, only $14 \%$ (613) of these unoiled samples were subjected to PAH analysis. Summary statistics of 2011 MESSh data were generated by assigning a sampling weight to each 2011 MESSh sample (Cochran 1977) to avoid biases due to stratified random sampling from finite populations. The sampling weight of marsh-edge samples was determined based on the weight of their 
co-located CWV sites. The sampling weight of each beach sample was calculated as the ratio of the total number of summer 2010 PA sites to the selected number of 2011 MESSh sites in the given stratum. Furthermore, the sampling weight of each unoiled sample was adjusted by the ratio of total number of unoiled samples collected to the number of unoiled samples analyzed for PAHs in the given stratum. For such data, computed summary statistics included weighted mean, standard deviation, as well as minimum and maximum values. All other tPAH data investigated in this work, including 2010 post-spill, were collected in accordance to unstratified plans, and hence, were not subjected to any sampling weight. For such data, computed summary statistics included unweighted mean and standard deviation, as well as minimum and maximum values.

\section{RESULTS}

\section{Ambient concentrations}

Ambient concentrations are key components of the exposure analysis. In this work, determination of ambient concentrations is complicated by the vastness of the investigated area, containing regions and zones with substantially different characteristics. For example, the delta region is heavily influenced by the Mississippi River runoffs, while the remote barrier islands are not only less affected by shore-based contamination, but also possess more active hydrodynamic environments when compared to nearshore coastal areas. To incorporate such regional characteristics, an innovative procedure based on forensic chemistry was devised. For this purpose, forensic results were used to identify ambient representative CWV soil and submerged sediment samples along various states and habitats. Each ambient representative sample was selected based on 2 conditions: (1) the sample was forensically identified as code $\mathrm{D}$, i.e. the sample does not match any field or DWH oil due to numerous nondetects or interferences (Emsbo-Mattingly 2015a), and (2) the sample was located at least $100 \mathrm{~m}$ from any DWH oil manifestation. These manifestations included shoreline segments or sites observed to be oiled by various survey teams, as well as tar ball, oil sheen, soil, sediment and tissue samples categorized as forensic code A or B. The purpose of the $100 \mathrm{~m}$ distance was to minimize the chances of having diluted DWH oil in ambient representative samples.

Summary statistics of ambient representative tPAH samples for various states, habitat types and dis- tances from the shore are listed in Table 2. Among the computed ambient tPAH concentration ranges, the highest values were from the Louisiana Delta Phragmites marsh area. In contrast, the lowest ambient $\mathrm{tPAH}$ concentrations occurred along barrier islands. Different ambient tPAH concentrations may partially be attributed to regional variations of TOC and grain size. In Louisiana Delta Phragmites marsh, the mean CWV soil TOC was $2 \%$, with an average of $60 \%$ fine particles. The mean CWV soil TOC in barrier islands was measured at $1 \%$, with mean percent fine particles of $34 \%$.

\section{Submerged sediment chemistry data}

The compiled data from 2010 post-spill and 2011 MESSh were separated into subsets based on their nearest shoreline oiling exposure category and vegetation status, as defined by Nixon et al. (2016). While most non-vegetated subsets provided adequate sample sizes (in excess of 8 samples), the only vegetated subsets large enough to warrant further analysis were along Louisiana shorelines, as shown in Table 3. This is primarily due to the fact that oiled shorelines in the other investigated states were predominantly non-vegetated, whereas oiled shorelines in Louisiana were dominated by vegetation (Nixon et al. 2016).

Nearshore tPAH concentrations show a clear decreasing pattern as distance to shore increases, with the highest values concentrated within the first $50 \mathrm{~m}$ from the shore, as depicted in Fig. 3 for Louisiana mainland salt/brackish herbaceous marsh sites. In this figure, ambient concentration ranges are shown as shaded intervals. Similar ranges for different shorelines and oiling exposures during 2010 and 2011 are provided in Figs. S1-S4 in the Supplement at www.int-res.com/articles/suppl/m576p111_supp.pdf, respectively. In all these figures, each sample is color coded based on its forensic code, with non-detects displayed as 0.001 parts per billion (ppb) values. These figures consistently indicate that the forensic code A/B samples with highest tPAH concentrations were situated primarily within the first $50 \mathrm{~m}$ from the shore. Summary statistics of 2010 post-spill and 2011 MESSh data, grouped by state, shoreline habitat type and oiling categories, and distance from the shore, are shown in Tables S2 \& S3 in the Supplement, respectively.

Comparison of the ambient tPAH concentration ranges in Table 2 with 2010 post-spill and 2011 MESSh results, indicates presence of elevated concentrations along oiled shorelines, especially within the 
Table 2. Summary statistics of ambient representative total polycyclic aromatic hydrocarbon (tPAH) concentrations following the DWH horizon oil spill in April 2010 through fall of 2011. Samples were taken from coastal wetland vegetation (CWV) soil, in submerged sediment within $50 \mathrm{~m}$ from the shore (Sediment 0-50) and in submerged sediment between 50 and $500 \mathrm{~m}$ from the shore (Sediment 50-500)

\begin{tabular}{|c|c|c|c|c|c|c|c|}
\hline \multirow[t]{2}{*}{ State } & \multirow[t]{2}{*}{ Habitat } & \multirow{2}{*}{ Location } & \multirow{2}{*}{$\begin{array}{l}\text { Sample } \\
\text { size }\end{array}$} & \multicolumn{4}{|c|}{ tPAH concentrations (ppb) } \\
\hline & & & & Mean & $\mathrm{SD}$ & Min & Max \\
\hline \multirow[t]{13}{*}{ Louisiana } & \multirow[t]{3}{*}{ Mainland herbaceous salt marsh } & CWV soil & 24 & 278 & 169 & 51 & 737 \\
\hline & & Sediment 0-50 & 58 & 264 & 422 & 8 & 2934 \\
\hline & & Sediment $50-500$ & 106 & 167 & 125 & 9 & 828 \\
\hline & \multirow[t]{2}{*}{ Back barrier herbaceous salt marsh } & CWV soil & 6 & 26 & 20 & 2 & 46 \\
\hline & & Sediment $50-500$ & 5 & 41 & 43 & 7 & 105 \\
\hline & \multirow[t]{3}{*}{ Coastal mangrove marsh } & CWV soil & 20 & 244 & 238 & 0 & 766 \\
\hline & & Sediment 0-50 & 3 & 74 & 1 & 73 & 75 \\
\hline & & Sediment $50-500$ & 6 & 109 & 109 & 7 & 238 \\
\hline & \multirow[t]{3}{*}{ Delta Phragmites } & CWV soil & 18 & 4278 & 5918 & 1211 & 24448 \\
\hline & & Sediment $0-50$ & 59 & 3015 & 3049 & 206 & 13521 \\
\hline & & Sediment $50-500$ & 57 & 1818 & 1920 & 425 & 13130 \\
\hline & \multirow[t]{2}{*}{ Non-vegetated } & Sediment 0-50 & 4 & 718 & 707 & 105 & 1506 \\
\hline & & Sediment $50-500$ & 43 & 513 & 664 & 0 & 2067 \\
\hline \multirow{2}{*}{$\begin{array}{l}\text { Mississippi/Alabama } \\
\text { (Mississippi Sound) }\end{array}$} & \multirow{2}{*}{$\begin{array}{l}\text { Mainland herbaceous salt marsh } \\
\text { Island herbaceous salt marsh }\end{array}$} & CWV soil & 30 & 254 & 225 & 19 & 953 \\
\hline & & CWV soil & 12 & 130 & 108 & 7 & 358 \\
\hline \multirow[t]{2}{*}{ Mississippi } & \multirow[t]{2}{*}{ Non-vegetated } & Sediment 0-50 & 11 & 1755 & 3313 & 3 & 9780 \\
\hline & & Sediment $50-500$ & 26 & 67 & 189 & 0 & 772 \\
\hline \multirow[t]{2}{*}{ Alabama } & \multirow[t]{2}{*}{ Non-vegetated } & Sediment $0-50$ & 8 & 124 & 218 & 0 & 640 \\
\hline & & Sediment $50-500$ & 38 & 68 & 130 & 0 & 526 \\
\hline Alabama (Perdido Bay) & Mainland herbaceous salt marsh & CWV soil & 9 & 210 & 278 & 3 & 679 \\
\hline \multirow[t]{2}{*}{ Florida } & \multirow[t]{2}{*}{ Non-vegetated } & Sediment $0-50$ & 45 & 100 & 201 & 0 & 896 \\
\hline & & Sediment $50-500$ & 58 & 152 & 412 & 0 & 2084 \\
\hline
\end{tabular}

first $50 \mathrm{~m}$ from the shore. The spatial presence of DWH oil is further confirmed by forensic code A/B samples, as shown in Fig. 4. This figure also shows the forensic code A/B classifications among stationary and chaindrag sentinel samples. These sentinel results confirm the presence and/or passage of oil in the water column and oil at the sediment-water interface.

\section{CWV soil chemistry data}

CWV soil chemistry data are available from fall 2010 to fall 2013 at a maximum of 188 fixed sites along the GOM. These measurements were taken from various habitats in Louisiana, Mississippi, and Alabama, which were investigated systematically

Table 3. Counts of submerged nearshore sediment samples with tPAH results in 2010 and 2011, by state, shoreline oiling category and shoreline type

\begin{tabular}{|c|c|c|c|c|c|c|}
\hline \multirow{2}{*}{$\begin{array}{l}\text { Shoreline oiling } \\
\text { category }\end{array}$} & \multirow[t]{2}{*}{ Shoreline type } & \multirow[b]{2}{*}{ Louisiana } & \multicolumn{3}{|c|}{ Sample size $(2010 / 2011)$} & \multirow[b]{2}{*}{ Texas } \\
\hline & & & Mississippi & Alabama & Florida & \\
\hline \multirow{2}{*}{$\begin{array}{l}\text { (1) Heavier persistent } \\
\text { oiling }\end{array}$} & Vegetated & $64 / 161$ & $0 / 0$ & $0 / 0$ & $0 / 0$ & $0 / 0$ \\
\hline & Non-vegetated & $15 / 17$ & $1 / 7$ & $0 / 0$ & $0 / 0$ & $0 / 0$ \\
\hline \multirow{2}{*}{ (2) Heavier oiling } & Vegetated & $139 / 180$ & $0 / 0$ & $0 / 0$ & $0 / 0$ & $0 / 0$ \\
\hline & Non-vegetated & $38 / 65$ & $8 / 14$ & $35 / 85$ & $33 / 36$ & $0 / 0$ \\
\hline \multirow[t]{2}{*}{ (3) Lighter oiling } & Vegetated & $98 / 229$ & $1 / 17$ & $3 / 2$ & $0 / 0$ & $0 / 0$ \\
\hline & Non-vegetated & $42 / 68$ & $45 / 39$ & $29 / 38$ & $40 / 34$ & $17 / 0$ \\
\hline \multirow[t]{2}{*}{ (4) No oil observed } & Vegetated & $154 / 420$ & $12 / 14$ & $11 / 54$ & $6 / 5$ & $0 / 0$ \\
\hline & Non-vegetated & $41 / 10$ & $7 / 28$ & $8 / 30$ & $35 / 75$ & $0 / 0$ \\
\hline \multirow[t]{2}{*}{ (5) Not surveyed } & Vegetated & $72 / 167$ & $7 / 3$ & $9 / 7$ & $88 / 78$ & $14 / 0$ \\
\hline & Non-vegetated & $4 / 0$ & $0 / 0$ & $0 / 0$ & $62 / 8$ & $37 / 0$ \\
\hline Total & & $667 / 1317$ & $81 / 122$ & $95 / 216$ & $264 / 236$ & $68 / 0$ \\
\hline
\end{tabular}




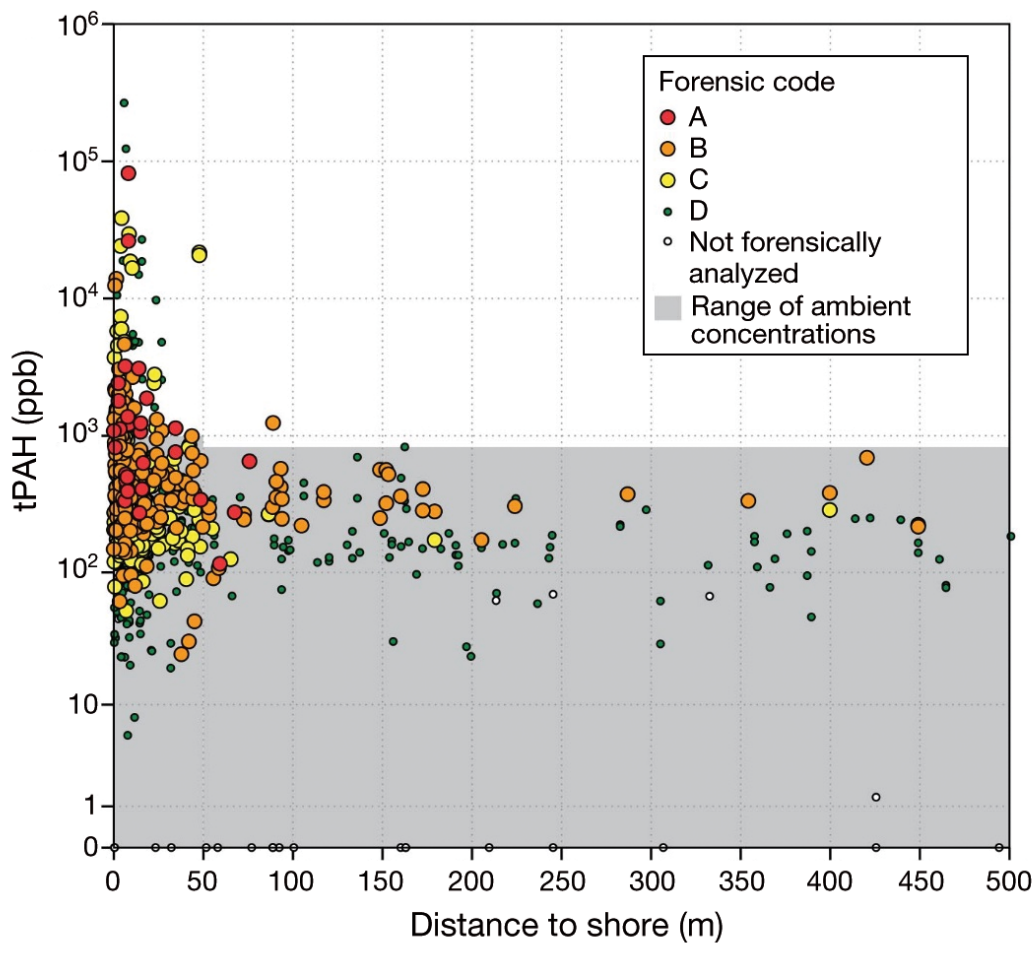

Fig. 3. Nearshore submerged sediment tPAH concentrations versus distance to shore along Louisiana mainland herbaceous salt marsh shorelines following the DWH oil spill. Samples were collected in 2010 and 2011. Forensic codes: $A=$ consistent with fresh or weathered DWH oil $; \mathrm{B}=$ mostly consistent with fresh or weathered DWH oil; $\mathrm{C}=$ some weathered DWH oil may be present; $\mathrm{D}=$ indeterminate
As noted, consistent with the stratified random CWV sampling plan, tPAH data were grouped by state/region, habitat type, season, PA plant oiling class, and zone. Weighted summary statistics for each group, including sample size, mean, standard error, minimum, maximum, and p-values, are presented in Table S6 in the Supplement. Plant oiling groups with significantly elevated tPAH concentrations relative to their corresponding reference values are highlighted as those with $\mathrm{p}$-values less than or equal to 0.05. Significantly elevated tPAH concentrations were mainly found along Louisiana mainland herbaceous salt marshes and occasionally back barrier herbaceous salt marshes and mangroves. The highest concentrations were generally reported along the oiled shoreline edge or Zone 1. For example, in the fall of 2010, at Louisiana mainland herbaceous salt marsh sites with 90 to $100 \%$ plant oiling, the mean tPAH concentration in Zone 1 was 65300 ppb, while Zones 2 and 3 (the interior exposure zones) reported 7420 and 6050 ppb, respectively (as shown in Table S6).

Although many oiled sites had tPAH concentrations that were significantly higher than

beginning in the fall of 2010 in Louisiana and spring of 2011 in Mississippi and Alabama through the fall of 2013. This dataset was used to quantitatively evaluate the spatial and temporal patterns of DWH oil exposure in various coastal wetland soils.

Forensic results confirmed the ubiquitous presence of DWH oil within impacted coastal wetlands (Fig. 5), especially those within Louisiana mainland herbaceous salt marshes. Along Louisiana mainland herbaceous salt marshes, $77 \%$ of samples from sites with 90 to $100 \%$ plant oiling, and $99 \%$ of samples from sites adjacent to heavier persistent oiling shorelines, were identified as either forensic code A or B (Table 4). The complete set of forensic results, classified by plant oiling classes and shoreline oiling exposure categories in various states and habitats, are summarized in Tables S4 \& S5 in the Supplement, respectively.

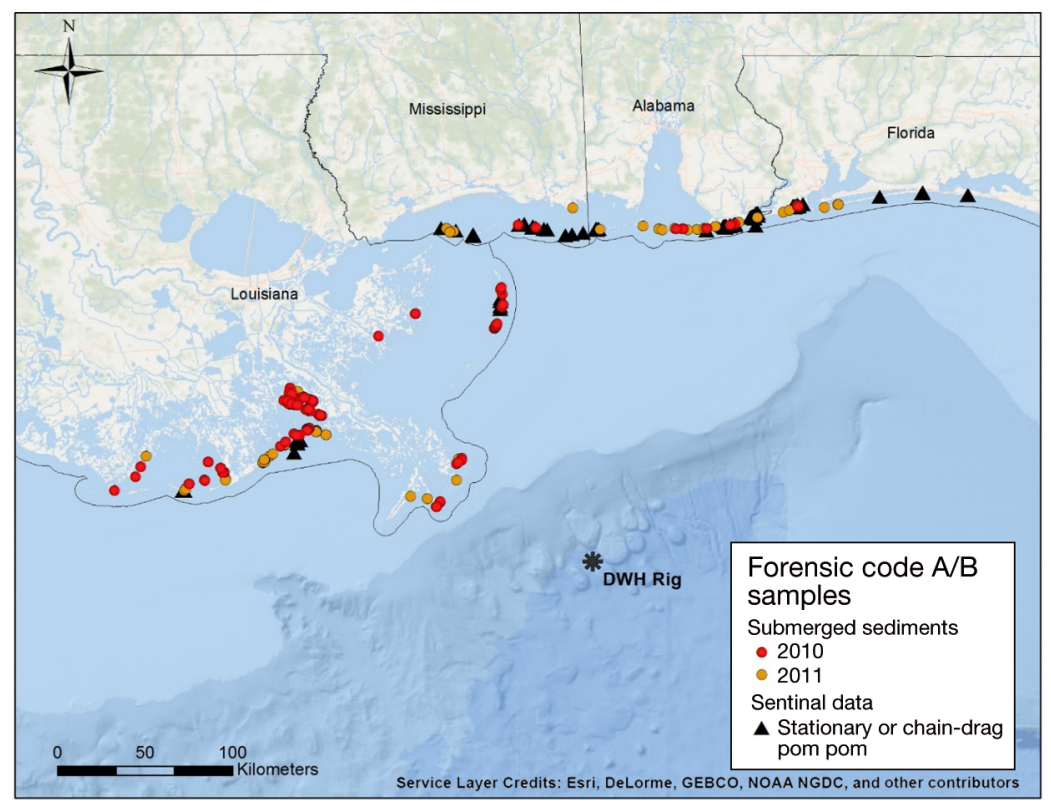

Fig. 4. Spatial distribution of forensic code A/B samples for submerged sediments and sentinel data along the northern coast of the Gulf of Mexico following the DWH oil spill. Forensic codes A/B are consistent (A) or mostly consistent (B) with fresh or weathered DWH oil 


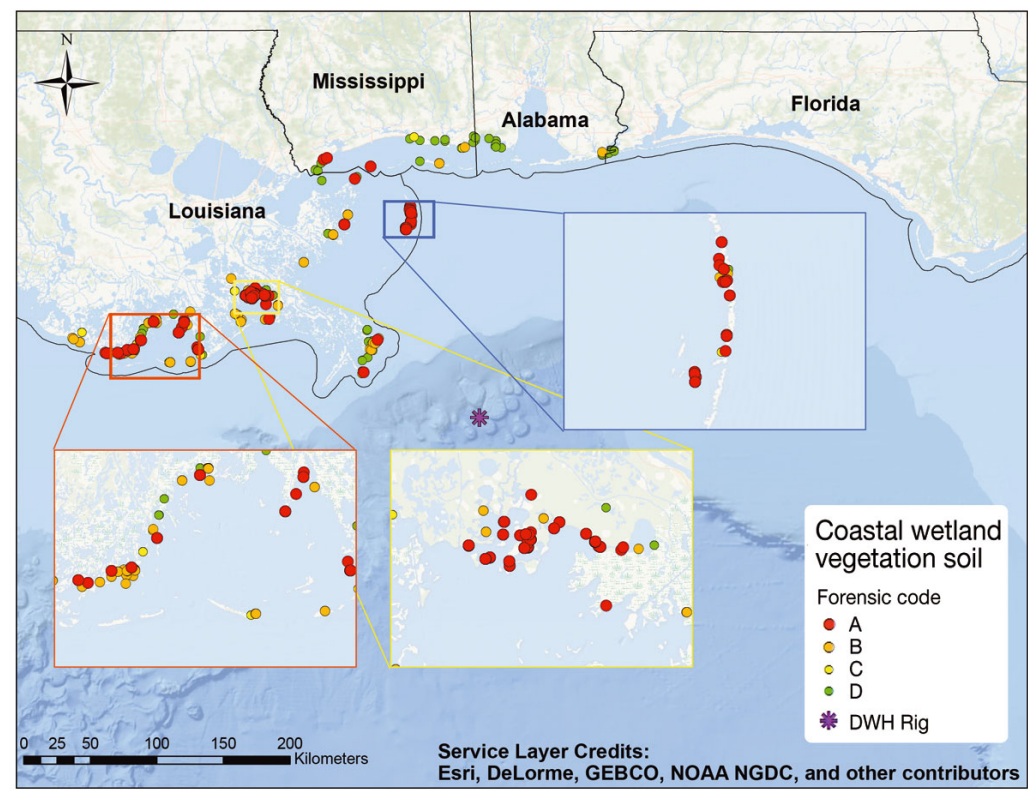

Fig. 5. Spatial distribution of coastal wetland vegetation (CWV) soil along the northern coast of the Gulf of Mexico following the DWH oil spill by results of forensic analysis. For key to forensic codes (A to D) see Fig. 3 legend. CWV soil samples collected in fall 2010 and spring 2011 were forensically analyzed; samples collected afterwards were not forensically analyzed. The three insets provide additional detail for areas where many sites are clustered and individual forensic codes may not be clear
Mann-Whitney $U$-tests between tPAH concentrations in oiled shoreline groups and their corresponding no-oilobserved values. An oiled shoreline group is considered as having significantly elevated $\mathrm{TPAH}$ concentrations if its mean exceeds the corresponding mean no-oil-observed value with a pvalue $\leq 0.05$. Significantly elevated tPAH concentrations occurred mainly along oiled shorelines of Louisiana mainland herbaceous salt marshes and occasionally in back barrier herbaceous salt marshes and mangroves, where the highest concentrations were reported along their edges. CWV soil data from other states and habitats were insufficient to determine significant tPAH occurrences above their corresponding no-oil-observed values.

When maximum precedent shoreline oiling exposure categories were used, the mean CWV soil tPAH concentrations displayed consistent, increasing patterns relative to shoreline oiling exposure categories. For exam- reference values, these concentrations did not display consistent, increasing trends relative to plant oiling. For example, mean tPAH concentrations at Louisiana mainland herbaceous salt marsh sites in Zone 1 in fall 2010 were $974 \mathrm{ppb}$ at reference sites ( $0 \%$ plant oiling) and 3350, 55100, 14100 and $65300 \mathrm{ppb}$ at sites with $0-10,10-50,50-90$ and 90-100\% plant oiling, respectively.

The absence of a consistent, increasing trend between $\mathrm{PAH}$ concentrations and PA plant oiling may be attributed to delayed oiling at some of the CWV sites; this includes sites that were heavily oiled after the summer 2010 PA survey but before the CWV surveys. In order to address delayed oiling, summary statistics based on maximum precedent shoreline oiling exposure categories were computed (Table S7 in the Supplement). For this purpose, exposure categories were treated as domains of study. Weighted statistics by states, habitat types, seasons, shoreline oiling exposure categories, and zones included sample size, mean, standard error, minimum, maximum, and p-values. The listed pvalues are associated with $t$-tests and
Table 4. Counts (percentages) of CWV soil samples within each forensic code in Louisiana mainland herbaceous salt marsh following the DWH oil spill, grouped by pre-assessment (PA) plant oiling class and shoreline oiling category. Forensic codes: $\mathrm{A}=$ consistent with fresh or weathered DWH oil $;$ B $=$ mostly consistent with fresh or weathered DWH oil $; \mathrm{C}=$ some weathered DWH oil may be present; D = indeterminate. Plant stem oiling was computed as the ratio of oiled portion of plant stems to dominant vegetation mean height

\begin{tabular}{|lcccc|}
\hline & \multicolumn{4}{c}{ Forensic code } \\
\cline { 2 - 5 } & A & B & C & D \\
\hline PA plant oiling class & & & & \\
$90-100 \%$ & $35(37)$ & $38(40)$ & $10(11)$ & $12(13)$ \\
$50-90 \%$ & $41(43)$ & $28(29)$ & $8(8)$ & $18(19)$ \\
$10-50 \%$ & $58(50)$ & $35(30)$ & $9(8)$ & $14(12)$ \\
$0-10 \%$ & $14(19)$ & $21(29)$ & $8(11)$ & $29(40)$ \\
$0-0 \%$ & $1(1)$ & $26(24)$ & $20(18)$ & $63(57)$ \\
Shoreline oiling exposure category & & & \\
Heavier persistent oiling & $86(82)$ & $18(17)$ & $1(1)$ & \\
Heavier oiling & $34(32)$ & $41(39)$ & $13(12)$ & $18(17)$ \\
Lighter oiling & $22(17)$ & $37(28)$ & $21(16)$ & $52(39)$ \\
No oil observed & $3(3)$ & $36(37)$ & $13(13)$ & $46(47)$ \\
Not surveyed & $4(9)$ & $16(34)$ & $7(15)$ & $20(43)$ \\
\hline
\end{tabular}




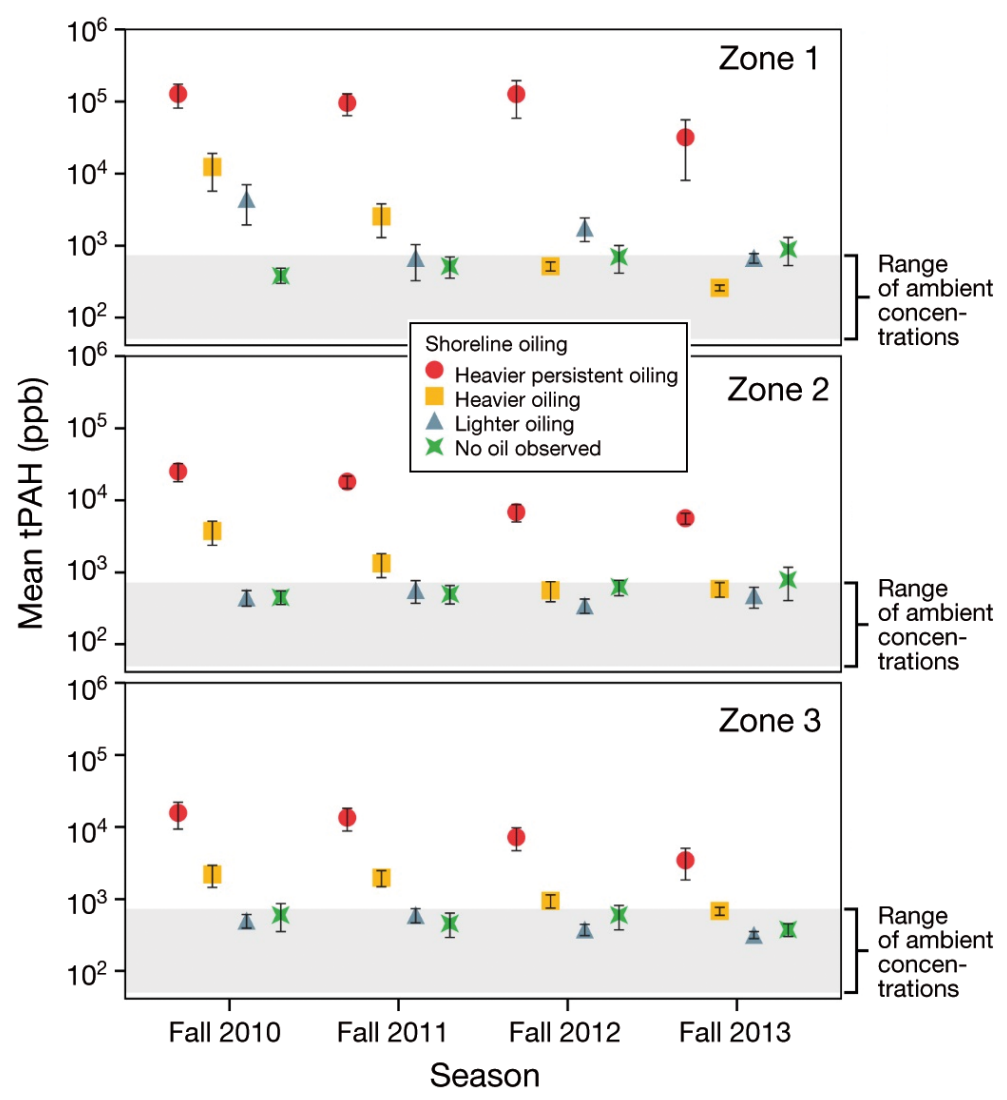

Fig. 6. Time series plots of soil tPAH concentrations for shoreline with different degrees of oiling in Louisiana mainland herbaceous salt marsh following the DWH oil spill in April 2010. Shaded areas show the range of ambient concentrations. Error bars represent $\pm \mathrm{SE}$

Fig. 6 displays zone-specific time series plots of weighted mean $\mathrm{TPAH}$ concentrations along various shoreline oiling categories of Louisiana mainland herbaceous salt marshes. In this figure, ambient concentration ranges are shown as shaded intervals. The figure depicts the gradual decline of CWV soil tPAH concentrations along oiled shorelines since the fall of 2010. However, the tPAH concentrations along heavier persistent oiling shorelines in all zones remained elevated above ambient ranges through the fall of 2013. Graphs for other states and habitats are provided as Figs. S5-S10 in the Supplement.

In the above analyses, fully eroded plots were considered as missing values. As indicated by the decreasing CWV sample sizes between the fall of 2010 and 2013 (Tables S6 \& S7), surveyed sites experienced various levels of land losses. For example, the number of Zone 1 plots in Louisiana mainland herbaceous salt marsh sites adjacent to heavier persistent oiling shorelines decreased from 13 in the fall of 2010 to only 4 in the fall of 2013. Such drops in sample sizes reduced the power to distinguish differences between oil and reference sites.

\section{Weathering of DWH oil}

Chemical weathering of DWH oil in the nearshore environment was investigated by focusing on petrogenic PAHs, i.e. 27 alkylated hydrocarbon compounds associated with petroleum, as listed in EmsboMattingly (2015a). The depletion was calculated as the average percent difference between relative abundances of individual petrogenic PAHs (PetPAHs) in forensic code A/B soil and sediment samples and those measured in fresh Macondo oil collected from the wellhead. In this case, the relative abundance of a PetPAH is calculated as the ratio of its abundance to hopane, a conservative internal marker within the oil (Emsbo-Mattingly 2015a). The computed depletion rates are greatly influenced by the environmental conditions in which the oil resides. These rates are representative of depletion at the time of sampling, and are not time-normalized. Time-normalization was not possible due the unknown time of the original release of the sampled oil.

Only data along Louisiana mainland herbaceous salt marshes were adequate for statistical summarizations, as listed in Table 5. These results indicate significant weathering of the DWH oil that penetrated vegetated shorelines. In both inland and offshore directions in 2010, the petrogenic PAH depletion rates were greater than $95 \%$ close to the shore and over $97 \%$ at further distances. Despite these already elevated rates, the petrogenic PAHs continued to deplete each year (Table 5).

\section{DISCUSSION}

\section{Spatial and temporal patterns of oil stranded in CWV soil}

The extensive CWV tPAH dataset was analyzed as a quantitative basis for evaluating temporal and spatial patterns of DWH oil exposures specifically along affected vegetated shorelines of Louisiana, Mississippi, and Alabama. As demonstrated by the forensic results, samples from vast regions of the northern GOM displayed chemical signatures of DWH oil. These samples included those collected at locations that had been previously identified as either no-oil- 
Table 5. Summary statistics of petrogenic polycyclic aromatic hydrocarbon (PAH) depletion rates along Louisiana mainland herbaceous salt marsh shorelines following the DWH oil spill based on forensic code A/B samples. Forensic codes A/B are consistent (A) or mostly consistent (B) with fresh or weathered DWH oil. Data are shown for coastal wetland vegetation (CWV) soils in 3 zones, with Zone 1 representing water edge conditions (approximately $1.5 \mathrm{~m}$ inland from the shoreline) and Zones 2 and 3 conditions progressively further inland; and for submerged sediments in 2 zones, $0-50 \mathrm{~m}$ and $50-500 \mathrm{~m}$ from the shore. These rates represent depletion at the time of sampling, and are not time-normalized

\begin{tabular}{|llrrrrr|}
\hline \multirow{2}{*}{ Matrix } & Position & $\begin{array}{c}\text { Sample } \\
\text { size }\end{array}$ & $\begin{array}{r}\text { Petrogenic } \\
\text { Mean }\end{array}$ & SD & Min & Max \\
\hline 2010 & & & & & & \\
CWV soil & Zone 3 & 35 & 97.5 & 1.0 & 94 & 99 \\
& Zone 2 & 38 & 97.5 & 0.8 & 95 & 99 \\
& Zone 1 (edge) & 40 & 95.7 & 2.2 & 90 & 98 \\
Submerged & 0-50 m from shore & 90 & 95.8 & 2.2 & 87 & 99 \\
sediment & 50-500 m from shore & 11 & 97.5 & 1.1 & 95 & 99 \\
2011 & & & & & & \\
CWV soil & Zone 3 & 36 & 97.5 & 1.8 & 91 & 99 \\
& Zone 2 & 38 & 97.7 & 1.3 & 94 & 99 \\
& Zone 1 (edge) & 37 & 96.7 & 1.6 & 93 & 99 \\
Submerged & 0-50 m from shore & 103 & 97.2 & 1.6 & 87 & 99 \\
sediment & 50-500 m from shore & 25 & 97.4 & 0.6 & 96 & 98 \\
& & & & & & \\
\hline
\end{tabular}

observed by SCAT and RA teams, or reference sites ( $0 \%$ plant oiling) by CWV survey teams. For example, $40 \%$ of the samples collected at sites along nooil-observed Louisiana mainland herbaceous shorelines were forensically identified as code A or B, albeit at concentrations lower than those measured at oiled sites. For the same habitat, $25 \%$ of the selected CWV reference sites were forensically identified as code A or B samples (Table 4). These results suggest that $\mathrm{tPAH}$ concentrations collected at locations identified as either reference or no-oil-observed cannot be automatically considered as representative of ambient conditions. Our forensic-based approach for determination of ambient concentrations addresses this conundrum and provides reliable, regionspecific results.

The computed ambient concentrations are displayed in Fig. 6, which shows zone-specific time series plots of weighted mean tPAH concentrations along various shoreline oiling categories of Louisiana mainland herbaceous salt marshes. This figure depicts the gradual decline of CWV soil tPAH concentrations along oiled shorelines since the fall of 2010. Similar results were reported by Turner et al. $(2014 \mathrm{a}, \mathrm{b})$ who investigated changes in the PAH concentrations subsequent to the DWH oil spill based on samples from a limited number of Louisiana marsh sites. Some of the tPAH concentration declines can be attributed to the erosion of plots along the oiled marsh edges of Louisiana.

\section{Spatial and temporal patterns of nearshore submerged oil}

The sediments affected by submerged oil were often overlain by a thin layer of flocculants containing oil. As described in Emsbo-Mattingly (2015b), sampling techniques implemented prior to 2011 were causing the loss of flocculants, likely resulting in underestimation of PAHs associated with sunken oil. Improved techniques resulted in the more efficient capture of flocculants during 2011 MESSh submerged sediment samplings.

As shown by our results, submerged sediments displayed patchy distributions of elevated PAH concentrations along oiled shorelines, with means 2 to 3 times higher than their corresponding ambient values, particularly adjacent to vegetated shorelines. PAH concentrations in submerged sediment were noticeably elevated above ambient values within the first $50 \mathrm{~m}$ from oiled shorelines. This $50 \mathrm{~m}$ range also contained the majority of forensic code A/B samples. Beyond the first $50 \mathrm{~m}$ from the shore, lower $\mathrm{PAH}$ concentrations were observed with sporadic forensic code A/B samples.

Determination of the temporal patterns of submerged sediment tPAH concentrations is often facilitated when co-located samples measured at different times are available. Although 2011 MESSh provided a comprehensive and balanced coverage of impacted shorelines, 2010 submerged sediment data were clustered along shorelines of concern. In addition, 2010 reported concentrations were likely biased low due to sampling techniques prone to flocculent losses. Of the thousands of submerged sediment samples collected in 2010 and 2011, only 112 pairs were within $100 \mathrm{~m}$ of each other between the 2 years. Given the spatial extent of the impacted shorelines, such a sample size is very small. However, review of the results suggested trends associated with the temporal patterns of submerged sediment tPAH concentrations. Of the 2010/2011 paired samples, 64 (or 57\%) indicated a decline in PAH concentrations between 2010 and 2011. Approximately $36 \%$ (23) of these 64 samples were forensic code $A / B$ in 2010. Of these 23 forensic code A/B samples, $83 \%$ (19) indicated a de- 
cline in tPAH concentrations between 2010 and 2011. The mean tPAH concentration of the 23 forensic code A/B samples was $1014 \mathrm{ppb}$ with standard error of $211 \mathrm{ppb}$, which decreased in 2011 to $406 \pm 85 \mathrm{ppb}$. This decrease was statistically significant with a parametric $p$-value of 0.013 (paired $t$-test) and a non-parametric p-value of 0.001 (Wilcoxon test).

Besides submerged oil tPAH data, SOMs, formed adjacent to beaches, were also observed during various response surveys (Michel et al. 2013). In general, SOMs are difficult to locate and require considerable skill to remove. According to Hayworth et al. (2011), SOMs can contain up to 90 percent sediment and range in thickness from a few millimeters to several centimeters. Oil in the interior of SOMs may resist weathering for many years, providing a source of oil and contaminants over time (Hayworth et al. 2011, Driskell \& Payne 2015, Emsbo-Mattingly \& Martin 2015).

\section{Previous oil spill exposures}

Multiple authors (Lee \& Page 1997, Nixon et al. 2013, Samaras et al. 2014) have explored the spatial and temporal distribution of nearshore exposure to past oil spills. These authors attributed the distribution of oil and its presence in the nearshore environment to a variety of factors, including oil type, coastal topography, beach permeability and stability, concentration of suspended sediments, and site-specific wave exposure. In studying the effects of the Exxon Valdez oil spill, Short et al. (2004) found that the most heavily oiled segments occurred within sheltered embayments where the largest initial landfall occurred. O'Clair et al. (1996) found some oil in deep subtidal sediments; however, the greatest concentration of oil was in shallow, nearshore submerged sediments at or near the land-water interface. Even at heavily oiled locations, there was little evidence of sediment contamination in water depths greater than $40 \mathrm{~m}$. Similar results were also reported by Lee \& Page (1997) based on a study of several spills. Studies of past spills, including the Exxon Valdez and Gulf War oil spills, also demonstrated that impacted soil and sediment samples adjacent to or within intertidal zones displayed elevated PAH concentrations consistent with observed oiling (O'Clair et al. 1996, Readman et al. 1996, Carls et al. 2001). These authors also demonstrated the gradual recovery of impacted resources, which was always accompanied by declining $\mathrm{PAH}$ concentration, although along the most heavily oiled locations, elevated PAH concentrations persisted years after the original impact.

\section{Conceptual model of nearshore exposure to DWH oil}

In the case of the DWH oil spill, the spatial and temporal distribution of the nearshore exposure has been analyzed by relying on data collected in NRDA efforts. Stout (2015a) discussed the chemical characteristics of the floating oil (or oil-on-water), while the daily spatial extent of oil-on-water was determined based on information from 4 different satellite-based sensors (Graettinger et al. 2015). Driskell \& Payne (2015) and Allan et al. (2012) explored the PAH patterns of the oil in water. PAH and forensic properties of stranded oil were studied by Stout (2015b) and Emsbo-Mattingly \& Martin (2015).

Graettinger et al. (2015) presented the extent of oilon-water for $68 \mathrm{~d}$ in 2010 subsequent to the DWH spill. Emsbo-Mattingly \& Martin (2015) demonstrated that the oil-on-water experienced substantial weathering, with petrogenic PAHs depleting at $61 \%$ on mean ( $65 \%$ median) before reaching the nearshore. Allan et al. (2012) observed temporary, significant increases in dissolved bioavailable PAH concentrations as the floating oil reached the shoreline at a few specific locations. Driskell \& Payne (2015) investigated a large number of 2010 nearshore water samples, including many from the first $50 \mathrm{~m}$ from the shore. They noted the general scarcity of particulate oil and the dominance of mostly dissolved- or indeterminate-phase oiled water samples. Of the investigated water samples, $36 \%$ were considered matches to DWH oil. The oil in these matching samples was predominantly attributed to leaching from previously deposited DWH oil, while the few samples with particulate components were related to resuspended oiled sediments (Driskell \& Payne 2015). Regarding stranded oil, Stout (2015b) and EmsboMattingly \& Martin (2015) conducted comprehensive forensic analyses of thousands of oil, tar ball, sheen, and soil samples. These results indicated widespread exposure to stranded DWH oil in the nearshore environments of the northern GOM.

To bring all these components together, a representative pictorial model of nearshore exposure was developed based on the results associated with forensic code A/B samples when compared with ambient representative samples. These results included 2011 CWV and 2011 MESSh samples along Louisiana mainland herbaceous salt marshes, whose summary statistics are displayed in Fig. 7. This figure indicates that within the stranded oil component of the model, the highest $\mathrm{PAAH}$ concentrations occurred along the seaward edge of marshes. These concentrations were 


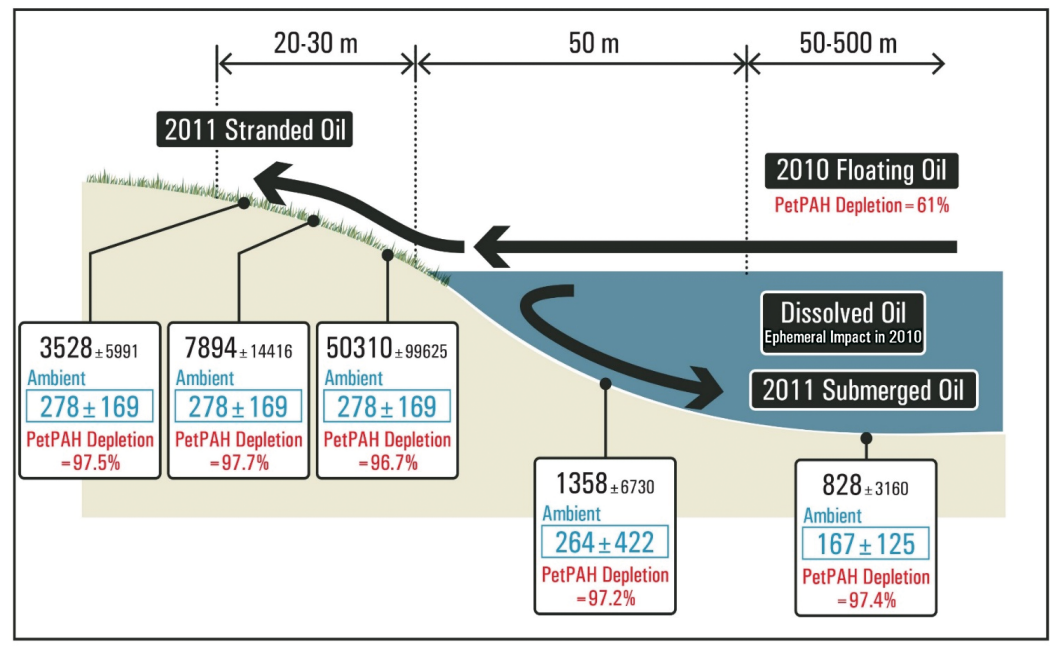

Fig. 7. Conceptual model of nearshore exposure to DWH oil based on 2011 forensic code A/B samples (for an explanation see Fig. 3) when compared to ambient samples along Louisiana herbaceous salt marsh shorelines. tPAH concentrations in 2011 (ppb, average $\pm \mathrm{SD}$ ) are displayed in black; ambient tPAH concentrations are displayed in blue. Average petrogenic PAH depletion rates in percent are shown in red. These rates represent depletion at the time of sampling, and are not timenormalized

orders of magnitude higher than their ambient levels (Table 2). In the submerged oil component of the model, the highest tPAH concentrations in excess of ambient levels occurred within the first $50 \mathrm{~m}$ from the shore. The elevated standard deviations of $\mathrm{PAH}$ in Fig. 7 highlight the patchy distribution of DWH oil through the nearshore environment.

Comparison of the 2010 and 2011 mean petrogenic PAHs depletion rate, listed in Table 5, indicates a gradual increase in the weathering of both stranded and submerged oil as distances to the shore, in both inland and offshore direction, increase (Fig. 7). Although $\mathrm{TPAH}$ concentrations were generally declining, elevated concentrations above ambient levels persisted along the most heavily oiled shorelines into 2013. In addition, DWH oil exposure may continue through leaching and resuspension of submerged and stranded oil.

The dissolved DWH oil component, in contrast to stranded and submerged oil, experienced ephemeral impacts (Allan et. al 2012). These authors noted that within $1 \mathrm{yr}$ after the arrival of the floating oil, nearshore water PAH concentrations reverted back to pre-oiling levels. Similar results were reported by Driskell \& Payne (2015), who indicated that the percentage of water samples matching DWH oil peaked during the summer and fall of 2010, with a far lower percentage of matches in the spring of 2011.

Acknowledgements. This work relies on data collected as part of the DWH Natural Resource Damage Assessment, which is being conducted cooperatively among National Oceanic and Atmospheric Administration (NOAA), other Federal and State Natural Resource agencies, and BP. Funding for the authors was provided through the NOAA Assessment and Restoration Division. The opinions presented in this work are those of the authors and not necessarily of all participants in the cooperative study upon which the work is based. We thank the field crew members who spent many days in the marshes of the GOM. We also thank the statistics teams who diligently compiled, reviewed, and analyzed the data, including Mike Wild, Lindsay Wallace, Leon Delwiche, George Desreuisseau, Mike Sieminski, Taylor Krieger, David Knorr, Colin Sutherland, Tatiana Manidis and Dr. Leyla Shams.

Supporting information. This material is freely available in the Supplement at www.int-res.com/articles/suppl/m576 p111_supp.pdf. It includes (1) summary statistics of forensic results in various states, habitats, shoreline oiling and plant oiling categories, (2) summary statistics of measured tPAH concentrations in wetland soils in various states, habitats, periods, shoreline oiling and plant oiling categories, (3) graphical presentation of mean $\mathrm{PAH}$ concentrations in wetland soils versus survey time in various states, habitats, and shoreline oiling exposures, (4) summary statistics of measured tPAH concentrations in various periods, states, habitats, and (5) graphical presentation of measured tPAH concentrations in submerged sediments versus distance from the shore in various periods, states, habitats, and shoreline oiling exposures.

\section{LITERATURE CITED}

Allan SE, Smith BW, Anderson KA (2012) Impact of the Deepwater Horizon oil spill on bioavailable polycyclic aromatic hydrocarbons in Gulf of Mexico coastal waters. Environ Sci Technol 46:2033-2039

Boufadel MC, Abdollahi-Nasab A, Geng X, Galt J, Torlapati J (2014) Simulation of the landfall of the Deepwater Horizon oil on the shorelines of the Gulf of Mexico. Environ Sci Technol 48:9496-9505

Brandt CA, Becker JM, Porta A (2002) Distribution of polycyclic aromatic hydrocarbons in soils and terrestrial biota after a spill of crude oil in Trecate, Italy. Environ Toxicol Chem 21:1638-1643

Carls MG, Babcock MM, Harris PM, Irvine GV, Cusick JA, Rice SD (2001) Persistence of oiling in mussel beds after the Exxon Valdez oil spill. Mar Environ Res 51:167-190

Cochran WG (1977) Sampling techniques, 3rd edn. John Wiley \& Sons, New York, NY

Driskell WB, Payne JR (2015) Forensic assessment of 2010 Deepwater Horizon nearshore water samples. (CHEM_ 
TR.22). Deepwater Horizon (DWH) Natural Resource Damage Assessment (NRDA) Chemistry Technical Working Group (TWG), Seattle, WA. https://pub-dwhdatadiver.orr.noaa.gov/dwh-ar-documents/946/DWHAR0039223.pdf

Emsbo-Mattingly SD (2015a) Chemical fingerprinting methodology and the classification of nearshore samples used in the Deepwater Horizon NRDA. DWH NRDA Chemistry TWG, Seattle, WA. https://pub-dwhdatadiver.orr. noaa.gov/dwh-ar-documents/946/DWH-AR0260571.pdf

Emsbo-Mattingly SD (2015b) Comparative evaluation of nearshore sediment sampling methods based on field trial in the northern GOM. DWH NRDA Chemistry TWG, Seattle, WA. https://pub-dwhdatadiver.orr.noaa.gov/dwh -ar-documents/946/DWH-AR0258636.pdf

Emsbo-Mattingly SD, Martin C (2015) Distribution and weathering of Macondo oil in nearshore soils, sediments, and tissues collected between spring 2010 to spring 2012 based on chemical fingerprinting methods. DWH NRDA Chemistry TWG, Seattle, WA. https://pub-dwhdatadiver. orr.noaa.gov/dwh-ar-documents/946/DWH-AR0260533. pdf

KEPA (United States Environmental Protection Agency) (2007) Method 8270 semivolatile organic compounds by gas chromatography/mass spectrometry (GC/MS), Revision 4. https://www.epa.gov/sites/production/files/201512/documents/8270d.pdf (updated version)

Forth HP, Morris JM, Cacela D (2015) Explanation of analytes included in the total polycyclic aromatic hydrocarbon sums used by the Deepwater Horizon Natural Resource Damage Assessment Toxicity Group. (TOX_ TR.11). DWH NRDA Toxicity TWG, Boulder, CO. https: //pub-dwhdatadiver.orr.noaa.gov/dwh-ar-documents/952/ DWH-AR0155464a.pdf

Graettinger G, Holmes J, Garcia-Pineda O, Hess M and others (2015) Integrating data from multiple satellite sensors to estimate daily oiling in the northern Gulf of Mexico during the Deepwater Horizon oil spill. (FE_TR.31). DWH NRDA Aerial Imagery TWG, Seattle, WA. https:// pub-dwhdatadiver.orr.noaa.gov/dwh-ar-documents/946/ DWH-AR0062879.pdf

*Hayworth JS, Clement TP, Valentine JF (2011) Deepwater Horizon oil spill impacts on Alabama beaches. Hydrol Earth Syst Sci 15:3639-3649

Lee RF, Page DS (1997) Petroleum hydrocarbons and their effects in subtidal regions after major oil spills. Mar Pollut Bull 34:928-940

Michel J, Owens EH, Zengel SA, Graham A and others (2013) Extent and degree of shoreline oiling: Deepwater Horizon oil spill, Gulf of Mexico, USA. PLOS ONE 8:e65087

*Nixon Z, Michel J, Hayes MO, Irvine GV, Short J (2013) Geomorphic factors related to the persistence of subsurface oil from the Exxon Valdez oil spill. J Coast Res 69: 115-127

Nixon Z, Zengel S, Baker M, Steinhoff M, Fricano G, Rouhani S, Michel J (2016) Shoreline oiling from the Deepwater Horizon oil spill. Mar Pollut Bull 107:170-178

NOAA (National Oceanic and Atmospheric Administration) (2010) Deepwater Horizon/MC252/BP shoreline/vegetation NRDA pre-assessment data collection plan, July 12, 2010. www.gulfspillrestoration.noaa.gov/wp-content/ uploads/2010/10/2010_07_30_SHORELINE_Pre-Assessment _Plan-REDACTED.pdf

NOAA (2011a) Sampling and monitoring plan for the assessment of MC252 oil impacts to coastal wetland vegetation in the Gulf of Mexico, August 4, 2011. www.gulfspillrestoration.noaa.gov/wp-content/uploads/2011_08_23_

Editorial responsibility: Sean Powers,

Dauphin Island, Alabama, USA (Guest Editor)
SHORELINE_Coastal_Wetland_Vegetation_La-Signature. redacted_Redacted3.pdf

NOAA (2011b) Assessment plan for marsh edges and sandy shorelines. NOAA Fish TWG of the Mississippi Canyon 252 Trustees, Seattle, WA. www.gulfspillrestoration. noaa.gov/wp-content/uploads/MarshedgeSandyShore line_AllSigned.Redacted.pdf

NOAA (2011c) Submerged oil characterization across multiple habitats for assessment of persistent exposures in nearshore sediments. NOAA Fish TWG of the Mississippi Canyon 252 Trustees, Seattle WA. www.gulfspillrestoration.noaa.gov/wp-content/uploads/2012/05/2011_ 07_06_NEARSHORE_Submerged-Oil-NOAA-BP_LASignature.redacted2.pdf

O'Clair CE, Short JW, Rice SD (1996) Contamination of intertidal and subtidal sediments by oil from the Exxon Valdez in Prince William Sound. In: Rice SD, Spies RB, Wolfe DA, Wright BA (eds) Proc Exxon Valdez Oil Spill Symp: Am Fisheries Soc Symp 18, Anchorage, AK. American Fisheries Society, Bethesda, MD, p 61-93

Readman JW, Bartocci J, Tolosa I, Fowler SW, Oregioni B, Abdulraheem MY (1996) Recovery of the coastal marine environment in the Gulf following the 1991 war-related oil spills. Mar Pollut Bull 32:493-498

Samaras AG, De Dominicis M, Archetti R, Lamberti A, Pinardi N (2014) Toward improving the representation of beaching in oil spill models: a case study. Mar Pollut Bull 88:91-101

Short JW, Jackson TJ, Larsen ML, Wade TL (1996) Analytical methods used for the analysis of hydrocarbons in crude oil, tissues, sediments, and seawater collected for the national resources damage assessment of the Exxon Valdez oil spill. In: Rice SD, Spies, RB, Wolfe DA, Wright BA (eds) Proc Exxon Valdez Oil Spill Symp: Am Fisheries Soc Symp 18. American Fisheries Society, Anchorage, AK, p 140-148

Short JW, Lindeberg MR, Harris PM, Maselko JM, Pella JJ, Rice SD (2004) Estimate of oil persisting on the beaches of Prince William Sound 12 years after the Exxon Valdez oil spill. Environ Sci Technol 38:19-25

* Stout SA (2015a) Range in composition and weathering among floating Macondo oils during the Deepwater Horizon oil spill. DWH NRDA Chemistry TWG, Seattle, WA. https://pub-dwhdatadiver.orr.noaa.gov/dwhar-documents/946/DWH-AR0038650.pdf

Stout SA (2015b) Distribution and weathering of Macondo oil stranded on shorelines in 2010 based on chemical fingerprinting. DWH NRDA Chemistry TWG, Seattle, WA. https://pub-dwhdatadiver.orr.noaa.gov/dwh-ar-documents/ 946/DWH-AR0038722.pdf

* Turner RE, Overton EB, Meyer BM, Miles MS, Hooper-Bui L (2014a) Changes in the concentration and relative abundance of alkanes and PAHs from Deepwater Horizon oiling of coastal marshes. Mar Pollut Bull 86:291-297

Turner RE, Overton EB, Meyer BM, Miles MS and others (2014b) Distribution and recovery trajectory of Macondo (Mississippi Canyon 252) oil in Louisiana coastal wetlands. Mar Pollut Bull 87:57-67

Wang Z, Christensen JH (2006) Crude oil and refined product fingerprinting: applications. In Morrison RD, Murphy BL (eds) Environmental forensics: contaminant specific guide. Academic Press, Oxford, p 410-464

Willis JM, Hester MW, Rouhani S, Steinhoff MA, Baker MC (2016) Field assessment of the impacts of Deepwater Horizon oiling on coastal marsh vegetation of Mississippi and Alabama. Environ Toxicol Chem, doi:10.1002/ etc. 3450

Submitted: February 1, 2016; Accepted: June 17, 2016

Proofs received from author(s): September 28, 2016 